\title{
PENGARUH KEPEMIMPINAN KEPALA SEKOLAH TERHADAP KOMPETENSI GURU DI SDN 035 TEMBILAHAN
}

\author{
Amanahtuzuriah \\ Alumni Manajemen Pendidikan Islam Universitas Islam Indragiri \\ Nurmadiah \\ Dosen Manajemen Pendidikan Islam Universitas Islam Indragiri

\section{Asmariani} \\ Dosen Manajemen Pendidikan Islam Universitas Islam Indragiri
}

\begin{abstract}
Abstrak
Kompetensi guru dalam melaksanakan tugas sebagai pendidik sangat perlu diperhatikan. Hal ini tidak terlepas dari kepemimpinan kepala sekolah, karena pemimpin yang baik akan senantiasa membina dan mengembangkan kompetensi gurunya melalui berbagai kegiatan. Diantaranya melalui Kegiatan Kerja Guru (KKG), seminar, lokakarya, dan sebagainya.Permasalahan dalam penelitian ini adalah: Bagaimana kepemimpinan kepala sekolah di SDN 035 Tembilahan? Bagaimana kompetensi guru di SDN 035 Tembilahan?Apakah ada pengaruh positif dan signifikan antara kepemimpinan kepala sekolah dengan kompetensi guru di SDN 035 Tembilahan? Kesimpulkandari penelitian ini bahwa Kepemimpinan Kepala Sekolah di SDN 035 Tembilahan memperoleh hasil persentase akhir 64,15 dikategorikan baik, dimana terletak pada interval 61-80\%. Kompetensi Guru di SDN 035 Tembilahan yang memperoleh hasil persentase akhir 77,13 dikategori baik, dimana terletak pada interval 61-80\%. Untuk mengetahui apakah ada pengaruh atau tidaknya, penulis melakukan analisis data dengan menggunakan regresi sederhana disimpulkan bahwa terdapat pengaruh yang positif dan signifikan antara kepemimpinan kepala
\end{abstract}


Vol. V, No. 1, April 2017

sekolah dengan kompetensi guru, karena $F_{\text {hitung }}=5,40>$ $F_{\text {tabel }}=4,15$ maka $H_{a}$ diterima dan $H_{o}$ ditolak. Dengan besar pengaruh yang diberikan 62,41 \% dan 37,59\% dipengaruhi faktor lain.

Kata kunci: Pengaruh, Kepemimpinan kepala sekolah dan kompetensi Guru

\section{A. Pendahuluan}

Sekolah merupakan sebuah tempat untuk menciptakan sumber daya manusia melalui kegiatan pendidikan, sebagai penghasil mutu pendidikan dalam berbagai pandangan lapisan masyarakat hingga saat ini masih disimpulkan dalam kategori rendah pada setiap satuan jenjang pendidikan, khususnya pada pendidikan dasar. Timbulnya pandangan seperti ini dipengaruhi oleh faktor kondisi dan realita yang dialami masing-masing kelompok masyarakat. Masyarakat pada dasarnya telah menyadari pada kondisi era globalisasi sekarang ini bahwa mutu pendidikan sudah menjadi prioritas untuk dapat diwujudkan oleh pemerintah. Salah satu indikator keberhasilan kepemimpinan seorang kepala sekolah diukur dari mutu pendidikan yang ada di sekolah yang dipimpinnya.

Sekolah sebagai pendidikan formal bertujuan membentuk manusia yang berkepribadian dalam mengembangkan intelektual peserta didik dalam rangka mencerdaskan kehidupan bangsa. Kepala sekolah sebagai pemimpin pendidikan perannya sangat penting untuk membantu guru dan muridnya. Dalam kepemimpinannya kepala sekolah harus dapat memahami, mengatasi dan memperbaiki 
kekurangan-kekurangan yang terjadi di lingkungan sekolah baik yang datang dari luar maupun dari dalam sekolah. ${ }^{1}$

Pendidikan nasional kita masih menghadapi aneka persoalan. Persoalan itu memang tidak akan pernah selesai, karena substansi yang ditransformasikan selama proses pendidikan dan pembelajaran selalu berada di bawah tekanan kemajuan ilmu pengetahuan, teknologi, dan kemajuan masyarakat. Beberapa persoalan pendidikan kita yang masih menonjol saat ini adalah rendahnya mutu proses dan keluaran pendidikan.

Buku pelajaran silih berganti, kurikulum yang terlalu membebani anak, dan lemahnya kompetensi sebagian guru. Padahal kompetensi merupakan modal utama guru untuk melaksanakan profesinya. Kompetensi adalah kemampuan yang dimiliki seseorang sehingga membolehkan ia untuk mengisi suatu peran. ${ }^{2}$ Kompetensi juga merupakan pengetahuan dan keterampilan yang menjadi kunci untuk menghasilkan output dari suatu pelatihan dan pengembangan peran mereka.

Kompetensi yang dimaksud meliputi kombinasi yang memanfaatkan knowledge, skills, dan behaviour untuk meningkatkan performans seorang pendidik dan pembelajar. Kemudian kompetensi guru meliputi: kompetensi kepribadian, kompetensi pedagogik, kompetensi profesional, dan kompetensi sosial. ${ }^{3}$

${ }^{1}$ Sahertian, Konsep-Konsep dan Teknik Supervisi Pendidikan Dalam Rangka Pengembangan Sumber Daya Manusia, (Jakarta: Rineka Cipta, 2000), h.18

2 Kunandar, Guru Profesional Implementasi KTSP dan Sukses dalam Sertifikasi Guru, (Jakarta: Rajawali Press, 2007), h. 70.

${ }^{3}$ Ibid., h, 71 . 
Vol. V, No. 1, April 2017

Kompetensi juga merupakan karakteristik dasar seseorang yang memiliki hubungan kausal dengan kriteria referensi efektivitas dan/atau keunggulan dalam pekerjaan atau situasi tertentu.

Karakter dasar diartikan sebagai kepribadian seseorang yang cukup dalam dan berlangsung lama, yaitu motif, karakteristik pribadi, konsep diri, dan nilai-nilai seseorang. Kriteria referensi berarti kompetensi dapat diukur berdasarkan kriteria atau standar tertentu.

Dalam sistem pendidikan dan pembelajaran dewasa ini, kehadiran guru dalam proses belajar mengajar masih tetap memegang peranan penting. Peranan guru dalam proses belajar mengajar belum dapat digantikan oleh mesin, radio, tape recorder, maupun oleh komputer yang paling modern sekalipun. Terlalu banyak unsur-unsur manusiawi seperti sikap, sistem nilai, perasaan, motivasi, kebiasaan dan lain-lain yang mampu meningkatkan proses pengajaran, tidak dapat dicapai melalui alat-alat tersebut. Di sinilah diperlukan kompetensi guru dalam melaksanakan tugas sebagai pendidik.

Hal ini tidak terlepas dari kepemimpinan kepala sekolah. Karena pemimpin yang baik akan senantiasa membina dan mengembangkan kompetensi gurunya melalui berbagai kegiatan. Diantaranya adalah melalui Kegiatan Kerja Guru (KKG), seminar, lokakarya, dan sebagainya, yang pelaksanaannya difasilitasi oleh kepala sekolah sebagai pemimpin.

Berdasarkan studi pendahuluan yang dilakukan ditemukan permasalahan yang ditunjukkan dengan gejala-gejala sebagai berikut: 
1. Masih ada guru yang belum memiliki kompetensi relevan dengan bidangnya yang dibuktikan dengan kepemilikan akta 4, namun mengajar di SDN 035Tembilahan.

2. Masih ada guru mengajar tidak sesuai dengan latar belakang pendidikan, namun tetap mengajarkan materi tersebut. Misalnya guru Olah raga yang tidak berlatar belakang pendidikan Sekolah Guru Olahraga.

3. Masih ada guru yang telah berkompetensi, namun belum mampu merealisasikan program kerja dalam proses pembelajaran.

4. Masih ada guru yang sudah berkompetensi, namun melalaikan tugas mengajarnya.

\section{B. Landasan Teori}

1. Kepemimpinan Kepala Sekolah

a. Pengertian Kepemimpinan

Kepemimpinan berasal dari kata "pimpin" yang memuat dua hal pokok, yaitu:

1) Pemimpin sebagai subjek

2) Yang dipimpin sebagai objek

Kata pimpin mengandung pengertian "mengarahkan, membina atau mengatur, menuntun dan juga menunjukkan ataupun mempengaruhi". ${ }^{4}$

\section{h. 518 .}

${ }^{4}$ Tim Reality, Kamus Bahasa Indonesia, (Surabaya: Reality Publisher, 2008), 
Vol. V, No. 1, April 2017

Menurut Stogdill sebagaimana dikutip oleh Daryanto, kepemimpinan adalah

"proses mempengaruhi kegiatan-kegiatan suatu kelompok yang diorganisasi, menuju kepada penentuan/pencapaian tujuan. Keberhasilan dan kegagalan pemimpin ditentukan oleh sifat dan gaya kepemimpinan dalam mengarahkan dinamika kelompoknya". 5

Dalam hal ini, Oteng Sutisna mengemukakan bahwa "kepemimpinan adalah kemampuan mengambil inisiatif dalam situasi sosial untuk menciptakan bentuk dan prosedur baru, merancang dan mengatur perbuatan, dan dengan berbuat begitu membangkitkan kerja sama ke arah tercapainya tujuan". 6

Definisi-definisi tersebut di atas memberi gambaran yang cukup luas dan mendalam tentang kepemimpinan. Beberapa rumusan lain yang dapat ditarik dari definisi di atas adalah:

a) Kepemimpinan adalah setiap perbuatan yang dilakukan oleh individu atau kelompok untuk mengkoordinasi dan memberi arah kepada individu atau kelompok yang tergabung di dalam wadah tertentu untuk mencapai tujuan yang telah ditetapkan sebelumnya.

b) Aktivitas pemimpin antara lain terjelma dalam bentuk memberi perintah, membimbing, dan mempengaruhi kelompok kerja atau orang lain dalam rangka mencapai tujuan tertentu secara efektif dan efisien.

5 Daryanto, Kepala Sekolah Sebagai Pemimpin Pembelajaran, (Yogykarta: Gava Media, 2002), h. 17.

${ }^{6}$ Oteng Sutisna, Pemimpin Profesional, (Bandung: Alfabeta, 2008), h. 16. 
c) Aktivitas pemimpin dapat dilukiskan sebagai seni dan bukan ilmu untuk mengkoordinasi dan memberikan arah kepada anggota kelompok dalam rangka mencapai suatu tujuan tertentu.

d) Memimpin adalah mengambil inisiatif dalam rangka situasi sosial (bukan perseorangan) untuk membuat prakarsa baru, menentukan prosedur, merancang perbuatan dan segenap kreativitas lain, dan karena itu pulalah tujuan organisasi akan tercapai.

e) Pemimpin selalu berada dalam situasi sosial, sebab kepemimpinan pada hakikatnya adalah hubungan antara individu dengan individu atau kelompok dengan individu atau kelompok lain. Individu atau kelompok tertentu disebut pimpinan dan individu atau kelompok lain disebut bawahan.

f) Pimpinan tidak memisahkan diri dari kelompoknya. Pimpinan bekerja dengan orang lain, bekerja melalui orang lain, atau keduanya. ${ }^{7}$

Selanjutnya pemimpin mempunyai tanggung jawab baik secara fisik maupun spiritual terhadap keberhasilan aktivitas kerja dari yang dipimpin, sehingga menjadi pemimpin itu tidak mudah dan tidak akan setiap orang mempunyai kesamaan didalam menjalankan kepemimpinannya.

\footnotetext{
${ }^{7}$ Sudarwan Danim, Kepemimpinan Pendidikan... h. 8-9.
} 
Vol. V, No. 1, April 2017

Secara kodrat bahwa manusia dilahirkan untuk menjadi pemimpin. Sejak Adam diciptakan sebagai manusia pertama dan diturunkan ke bumi, Ia ditugasi sebagai Khalifah fil ardhi. Sebagaimana termaktub dalam Al Quran Surat Al Baqarah ayat 30 yang berbunyi:

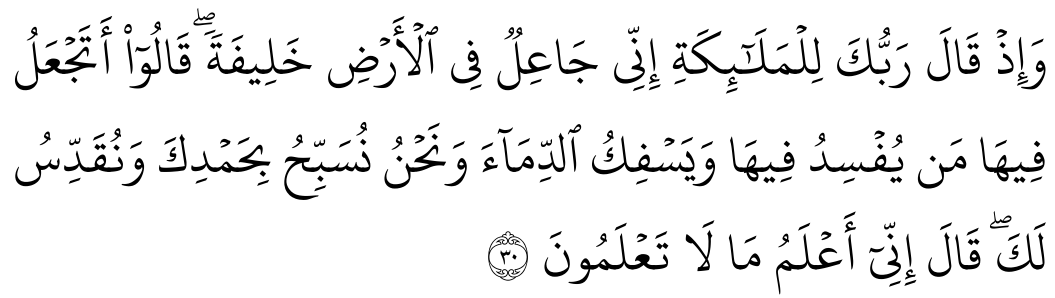

"Ingatlah ketika Tuhanmu berfirman kepada Malaikat"; "Sesungguhnya Aku akan mengangkat Adam menjadi Khalifah di muka Bumi". Menurut Bachtiar Surin yang dikutip Maman Ukas bahwa "Perkataan Khalifah berarti penghubung atau pemimpin yang diserahi untuk menyampaikan atau memimpin sesuatu" (QS.A1 Baqarah ayat 30). ${ }^{8}$

Dalam pengertian ini berarti dalam satu kelompok baik kecil maupun besar harus ada seorang pemimpin. Pemimpin harus dapat memberi arahan pada bawahannya agar tujuan bisa tercapai. Sekolah sebagai wadah berkumpulnya warga sekolah harus dipimpin oleh seorang kepala sekolah. Ibarat sebuah kapal (sekolah) dijalankan seorang nakhoda. Nakhoda yang akan membawa arah dan tujuan kapal berlabuh. Demikian juga halnya sekolah harus dipimpin oleh kepala sekolah, agar sekolah dapat berjalan dengan tujuan yang ditetapkan bersama.

${ }^{8}$ Q.S. 2 : 30. 
Menurut Sudarwan Danim dalam bukunya yang berjudul Kepemimpinan Pendidikan, kepemimpinan adalah setiap tindakan yang dilakukan oleh individu atau kelompok untuk mengkoordinasi atau memberi arah kepada individu atau kelompok lain yang tergabung dalam wadah tertentu untuk mencapai tujuan-tujuan yang telah ditetapkan sebelumnya. ${ }^{9}$

Menurut Edlwin A. Fleishmen sebagaimana dikutip oleh Maimunah, "Kepemimpinan adalah kemampuan mempengaruhi, memberi inspirasi, dan mengarahkan tindakan seseorang atau kelompok melalui proses komunikasi untuk mencapai tujuan yang diharapkan". ${ }^{10}$ Sedangkan menurut Turmudi yang dikutip oleh Herabudin, Kepemimpinan merupakan kegiatan seorang pemimpin dalam mengendalikan dan mengarahkan para pengikutnya dalam mencapai tujuan bersama. $^{11}$

Kepemimpinan kepala sekolah merupakan bentuk dari kinerja kepala sekolah sebagai pemimpin yang mengarahkan serta membimbing bawahan seperti guru dan staf kependidikan secara terpadu guna melaksanakan program pendidikan yang telah disusun dan direncanakan sebelumnya.

Dari pendapat tersebut, maka yang dimaksud dengan kepemimpinan kepala sekolah adalah keseluruhan dari

\footnotetext{
${ }^{9}$ Sudarwan Danim, Kepemimpinan Pendidikan... h. 6

${ }_{10}$ Maimunah, Manajemen Konflik dan Strategi Kepemimpinan Rasulullah
} SAW, (Yogyakarta: Total Media, 2013), h. 31

${ }^{11}$ Herabudin, Administrasi dan Supervisi Pendidikan, (Bandung: Pustaka Setia, 2009), h. 185 
Vol. V, No. 1, April 2017

keterampilan dan sikap yang diperlukan oleh kepala sekolah dalam memimpin atau mengarahkan bawahan yang dipimpinnya yang merupakan kombinasi dari serangkaian perangai yang memungkinkan seseorang mampu mendorong orang lain untuk menjalankan tugas-tugas tertentu.

b. Fungsi Kepemimpinan kepala Sekolah

Kepala sekolah harus berusaha agar semua potensi yang ada di sekolahnya, baik potensi yang ada pada unsur manusia maupun yang ada pada alat, perlengkapan, keuangan, dan sebagainya dapat dimanfaatkan sebaik-baiknya agar tujuan sekolah dapat tercapai. Fungsi kepemimpinan kepala sekolah dapat dilihat dari aspek sebagai berikut:

1) Kepala sekolah sebagai Educator (pendidik)

"Sebagai educator", kepala sekolah harus senantiasa berupaya meningkatkan kualitas pembelajaran yang dilakukan oleh para guru. Dalam hal ini faktor pengalaman akan sangat mempengaruhi kecakapan kepala sekolah, terutama dalam mendukung terbentuknya pemahaman tenaga kependidikan terhadap pelaksanaan tugasnya.

2) Kepala sekolah Sebagai Manajer

Seorang manajer atau seorang kepala sekolah pada hakikatnya adalah seorang perencana, organisator, pemimpin, dan seorang pengendali. Keberadaan manajer pada suatu organisasi sangat diperlukan, sebab organisasi sebagai alat mencapai tujuan organisasi. 
Didalamnya berkembang berbagai macam pengetahuan, serta organisasi yang menjadi tempat untuk merencanakan, mengorganisasi, memimpin, dan mengendalikan agar organisasi dapat mencapai tujuan yang telah ditetapkan.Seorang kepala sekolah harus memiliki strategi yang tepat untuk memperdayakan tenaga kependidikan melalui kerjasama dan mendorong keterlibatan seluruh tenaga kependidikan dalam melaksanakan berbagai kegiatan yang menunjang program sekolah.

3) Kepala Sekolah Sebagai Administrator

Kepala sekolah memiliki hubungan yang sangat erat dengan berbagai aktivitas pengelolaan administrasi yang bersifat pencatatan, penyususnan dan pendokumenan seluruh program sekolah. Secara spesifik, kepala sekolah harus memiliki kemampuan untuk mengelola kurikulum, mengelola administrasi peserta didik, mengelola administrasi personalia, mengelola administrasi sarana dan prasarana, mengelola administrasi kearsipan, dan mengelola administrasi keuangan. Kegiatan tersebut perlu dilakukan secara efektif dan efisien agar dapat menunjang produktivitas sekolah.

4) Kepala Sekolah Sebagai Supervisor

Kepala sekolah harus mampu melakukan berbagai pengawasan dan pengendalian untuk meningkatkan 
kinerja tenaga kependidikan. Pengawasan dan pengendalian ini merupakan kontrol agar kegiatan pendidikan di sekolah terarah pada tujuan yang telah ditetapkan. Pengawasan dan pengendalian juga merupakan tindakan preventif untuk mencegah agar para tenaga kependidikan tidak melakukan penyimpangan dan lebih berhati-hati dalam melaksanakan pekerjaannya.

5) Kepala Sekolah Sebagai Leader

Kepala sekolah harus mampu memberikan petunjuk dan pengawasan, meningkatkan kemauan tenaga kependidikan, membuka komunikasi dua arah, dan mendelegasikan tugas.

6) Kepala Sekolah Sebagai Inovator

Kepala sekolah harus memiliki strategi yang tepat untuk menjalin hubungan yang harmonis dengan lingkungan, mencari gagasan baru, mengintegrasikan setiap kegiatan, memberikan teladan kepada seluruh tenaga kependidikan sekolah, dan mengembangkan modelmodel pembelajaran yang inovatif.

7) Kepala Sekolah Sebagai Motivator

Kepala sekolah harus memiliki strategi yang tepat untuk memberikan motivasi kepada para tenaga kependidikan dalam melakukan berbagai tugas dan fungsinya, motivasi ini dapat ditumbuhkan melalui pengaturan lingkungan fisik, pengaturan suasana kerja, disiplin, 
dorongan, penghargaan secara efektif dan penyediaan berbagai sumber belajar melalui pengembangan pusat sumber belajar. ${ }^{12}$

c. Syarat-Syarat Kepemimpinan Kepala Sekolah

Kepala sekolah termasuk pemimpin formal dalam lembaga pendidikan. Diartikan sebagai kepala, karena kepala sekolah adalah pejabat tertinggi di sekolah. ${ }^{13}$ Untuk meningkatkan kualitas pendidikan seorang kepala sekolah harus mampu meningkatkan kinerja para guru atau bawahannya. Banyak faktor yang dapat mempengaruhi kinerja seseorang, sebagai pemimpin sekolah harus mampu memberikan pengaruh-pengaruh yang dapat menyebabkan guru tergerak untuk melaksanakan tugasnya secara efektif sehingga kinerja mereka akan lebih baik.

Sebagai pemimpin yang mempunyai pengaruh, ia berusaha agar nasehat, saran dan perintahnya diikuti oleh guruguru. Dengan demikian ia dapat mengadakan perubahanperubahan dalam cara berfikir, sikap, tingkah laku yang dipimpinnya. Dengan kelebihan yang dimilikinya yaitu kelebihan pengetahuan dan pengalaman, ia membantu guruguru berkembang menjadi guru yang profesional.

Adapun syarat-syarat kepemimpinan dapat diperincikan sebagai berikut:

12 E. Mulyasa, Menjadi Kepala Sekolah Profesional, (Bandung: PT. Remaja Rosdakarya, 2006), h. 98-120.

${ }^{13}$ Herabudin, Administrasi dan Supervisi Pendidikan... h. 200. 
1) Kemampuan pengawasan dalam kedudukan atau pelaksanaan fungsi-fungsi manajemen terutama pengarahan dan pengawasan kerjaan orang lain (para bawahan).

2) Kebutuhan akan prestasi dalam pekerjaan, mencakup pencarian tanggungjawab dan keinginan untuk sukses.

3) Kecerdasan, mencakup kebijaksanaan, pemikiran kreatif dan daya pikir.

4) Ketegasan, atau kemampuan untuk membuat keputusankeputusan dan memecahkan masalah-masalah dengan cakap dan tepat.

5) Kepercayaan diri, atau pandangan terhadap dirinya sebagai kemampuan untuk menghadapi masalahmasalah.

6) Inisiatif, atau kemampuan untuk bertindak tidak tergantung, mengembangkan serangkaian aktifitas dan menentukan cara-cara baru atau inovasi. ${ }^{14}$

Oleh karena itu, segala penyelenggaraan pendidikan akan mengarah kepada usaha meningkatkan mutu pendidikan yang sangat dipengaruhi oleh guru dalam melaksanakan tugasnya secara operasional. Untuk itu kepala sekolah harus melakukan supervisi sekolah yang memungkinkan kegiatan operasional itu berlangsung dengan baik.

${ }^{14}$ Tholib Kasan, Teori dan Aplikasi Administrasi Pendidikan, (Jakarta: Studia Press, 2006), h. 138. 
Kepemimpinan kepala sekolah memiliki pengaruh positif terhadap pencapaian tujuan dan hasil sekolah. Kemampuan dan keterampilan kepala sekolah dalam mengelola institusi pendidikannya secara profesional, menjadi salah satu aspek yang menyebabkan sekolah menjadi efektif. ${ }^{15}$

\section{Kompetensi Guru}

a. Pengertian Kompetensi Guru

Istilah competencies, competence, dan competent diterjemahkan sebagai kompetensi, kecakapan, dan keberdayaan merujuk pada keadaan atau kualitas mampu dan sesuai. ${ }^{16}$

Menurut Jhonson sebagaimana dikutip oleh Syaiful Sagala, kompetensi merupakan "perilaku rasional guna mencapai tujuan yang dipersyaratkan sesuai dengan kondisi yang diharapkan". ${ }^{17}$

Sementara itu Udin Syaefudin Saud menjelaskan definisi kompetensi sebagai berikut:

"Competence yang menunjuk pada kecakapan atau kemampuan untuk mengerjakan suatu pekerjaan, competent yang menunjuk pada sifat orang-orang yang memiliki kecakapan, kemampuan, kemahiran dan pengetahuan, serta

${ }^{15}$ Iskandar Agung dan Yufridawati, Pengembangan Pola Kerja Harmonis dan Sinergis Antara Guru, Kepala Sekolah, dan Pengawas, (Jakarta: Bestari Buana Murni, 2013), h. 107.

${ }^{16}$ Martinis Yamin dan Maisah, Standarisasi Kinerja Guru, (Jakarta: Gaung Persada Press, 2010), h. 5.

${ }^{17}$ Syaiful Sagala, Kemampuan Profesional Guru dan Tenaga Kependidikan, (Bandung: Alfabeta, 2009), h. 23. 
competency yang menunjuk pada tindakan rasional dalam mencapai tujuan secara memuaskan sesuai dengan harapan". ${ }^{18}$

Guru merupakan salah satu faktor utama yang menentukan kualitas pendidikan. Gurulah yang berada di garda terdepan dalam menciptakan kualitas sumber daya manusia. Guru berhadapan langsung dengan para peserta didik di kelas melalui proses belajar mengajar.

Guru yang profesional adalah guru yang memiliki kompetensi yang dipersyaratkan untuk melakukan tugas pendidikan dan pengajaran. Menurut Usman, kompetensi adalah

"Suatu hal yang menggambarkan kualifikasi atau kemampuan seseorang, baik yang kualitatif maupun yang kuantitatif. Pengertian ini mengandung makna bahwa kompetensi itu dapat digunakan dalam dua konteks, yakni: pertama sebagai indikator kemampuan yang menunjukkan kepada perbuatan yang diamati. Kedua sebagai konsep yang mencakup aspekaspek kognitif, afektif dan perbuatan serta tahap-tahap pelaksanaannya secara utuh". ${ }^{19}$

Pendapat lain menyatakan kompetensi seperti yang dikutip oleh Kunandar dari pendapat W.Robert Houston adalah sebagai

"Suatu tugas memadai atau pemilikan pengetahuan, keterampilan, dan kemampuan yang dituntut oleh jabatan tertentu. Sedangkan Piet dan Ida Sahertian mengatakan bahwa kompetensi adalah kemampuan melaksanakan sesuatu yang

${ }^{18}$ Udin Syaefudin Saud, Pengembangan Profesi Guru, (Bandung: Alfabeta, 2009), h. 44-45.

19 Moh. Uzer Usman, Menjadi Guru Profesional, (Bandung: Remaja Rosdakarya, 2003), h. 56. 
diperoleh melalui pendidikan dan pelatihan yang bersifat kognitif, afektif, dan psikomotor". ${ }^{20}$

Dengan menyimak makna kompetensi tersebut di atas, maka dapat dimaklumi jika kompetensi itu dipandang sebagai pilarnya atau teras kinerja dari suatu profesi. Hal itu mengandung implikasi bahwa seorang profesional yang kompeten itu harus dapat menunjukkan karakteristik utamanya antara lain:

1) Mampu melakukan suatu pekerjaan tertentu secara rasional.

2) Menguasai perangkat pengetahuan tentang bidang tugas dan pekerjaannya.

3) Menguasai perangkat keterampilan tentang cara melakukan tugas pekerjaannya.

4) Memahami perangkat persyaratan standar tentang ketentuan kelayakan normatif minimal kondisi dari proses yang dapat ditoleransikan dan kriteria keberhasilan yang dapat diterima dari apa yang dilakukannya.

5) Memiliki daya dan citra u nggulan dalam melakukan tugas pekerjaannya. ${ }^{21}$

20 Kunandar, Guru Profesional Implementasi KTSP dan Sukses dalam Sertifikasi Guru, (Jakarta: Rajawali Press, 2008), h. 45.

${ }^{21}$ Ibid., h. 47. 
Vol. V, No. 1, April 2017

b. Komponen Kompetensi Guru

Direktorat Tenaga Kependidikan Departemen Pendidikan Nasional, Undang-Undang Republik Indonesia Nomor 20 Tahun 2003 tentang Standar Kompetensi Guru, meliputi empat komponen, yaitu: "pengelolaan pembelajaran, pengembangan potensi, penguasaan akademik, dan sikap kepribadin". 22

Dalam Undang-undang Guru dan Dosen Nomor 14/2005 dan Peraturan Pemerintah Nomor 19/2005 dinyatakan bahwa kompetensi guru meliputi "kepribadian, paedagogik, profesional, dan sosial". ${ }^{23}$

Keempat jenis kompetensi tersebut dijelaskan di bawah ini:

1) Kompetensi Kepribadian

Setiap perkataan, tindakan, dan tingkah laku positif akan meningkatkan citra diri dan kepribadian seseorang, selama hal itu dilakukan dengan penuh kesadaran.

Dilihat dari aspek psikologi, kompetensi kepribadian guru merupakan kemampuan personal yang mencerminkan kepribadian yang mantap, stabil, dewasa,

${ }^{22}$ Undang-Undang Republik Indonesia Nomor 20 Tahun 2003 tentang Standar Kompetensi Guru.

${ }^{23}$ Undang-undang Guru dan Dosen Nomor 14/2005 dan Peraturan Pemerintah Nomor 19/2005. 
arif, dan berwibawa, menjadi teladan bagi peserta didik, dan berakhlak mulia. ${ }^{24}$

Kompetensi kepribadian menyangkut sikap kepribadian yang mantap atau matang sehingga mampu berfungsi sebagai tokoh identitas bagi siswa serta dapat menjadi panutan bagi siswa dan masyarakatnya. ${ }^{25}$

Sebagai sesuatu yang abstrak, kepribadian sukar dilihat secara nyata, hanya dapat diketahui lewat penampilan, tindakan, dan ucapan ketika menghadapi suatu persoalan, atau melalui atsarnya saja. Kepribadian mencakup semua unsur, baik fisik maupun psikis. Sehingga dapat diketahui bahwa setiap tindakan dan tingkah laku seseorang merupakan cerminan dari kepribadian seseorang. Apabila nilai kepribadian seseorang naik, maka akan naik pula kewibawaan orang tersebut. Tentu dasarnya adalah ilmu pengetahuan dan moral yang dimilikinya. Kepribadian akan turut menentukan apakah para guru dapat disebut sebagai pendidik yang baik atau sebaliknya, justru menjadi perusak anak didiknya. ${ }^{26}$

Dari uraian di atas dapat disimpulkan bahwa kompetensi kepribadian guru merupakan kemampuan untuk berperilaku bijak kepada semua pihak, baik dalam

${ }^{24}$ Martinis Yamin dan Maisah, Standarisasi Kinerja Guru... h. 9.

25 Ibrahim Bafadal, Peningkatan Profesionalisme Guru, (Jakarta: Bumi Aksara, 2003), h. 42.

${ }^{26}$ Ibid., h. 43 
dunia pendidikan maupun dalam kehidupan sehari-hari yang dapat dirincikan sebagai berikut:

a) Konsisten dalam bertindak sesuai norma dan etika yang berlaku.

b) Bijaksana dalam bertindak.

c) Memiliki perilaku yang dapat diteladani.

2) Kompetensi Paedagogik

Kompetensi paedagogik meliputi pemahaman terhadap peserta didik, perencanaan dan pelaksanaan pembelajaran, evaluasi hasil belajar, dan pengembangan peserta didik untuk mengaktualisasikan berbagai potensi yang dimilikinya. ${ }^{27}$

Dengan mengutip pendapat Syaiful Sagala berpandangan bahwa kompetensi paedagogik merupakan kemampuan dalam pengelolaan peserta didik meliputi:

"Pemahaman wawasan guru akan landasan dan filsafat pendidikan, guru memahami potensi dan keberagaman peserta didik, sehingga dapat didesain strategi pelayanan belajar sesuai keunikan masing-masing peserta didik, guru mampu mengembangkan kurikulum/silabus baik dalam bentuk dokumen maupun implementasi dalam bentuk pengalaman belajar, guru mampu menyusun rencana dan strategi pembelajaran berdasarkan standar kompetensi dan kompetensi dasar, mampu melaksanakan pembelajaran yang 
mendidik dengan suasana dialogis dan interaktif sehingga pembelajaran menjadi aktif, inovatif, kreatif, efektif, dan menyenangkan, mampu melakukan evaluasi hasil belajar dengan memenuhi prosedur dan standar yang dipersyaratkan, dan mampu mengembangkan bakat dan minat peserta didik melalui kegiatan intrakurikuler dan ekstrakurikuler untuk mengaktualisasikan berbagai potensi yang dimilikinya". ${ }^{28}$

Kompetensi pedagogik merupakan kemampuan guru dalam memahami ilmu kependidikan yang pada umumnya diperoleh melalui lembaga pendidikan, yang dapat dirincikan sebagai berikut:

a) Memahami landasan kependidikan.

b) Memahami keberagaman siswa.

c) Mengembangkan silabus.

d) Menyusun rencana dan strategi pembelajaran.

e) Melaksanakan pembelajaran yang mendidik dan dialogis.

f) Melakukan evaluasi hasil belajar.

g) Mengembangkan bakat dan minat siswa melalui kegiatan intrakurikuler dan ekstrakurikuler. ${ }^{29}$

Dari beberapa teori di atas dapat disimpulkan bahwa kompetensi paedagogik adalah sebagai berikut: h. 32 .

${ }^{28}$ Syaiful Sagala, Kemampuan Profesional Guru dan Tenaga Kependidikan...

${ }^{29}$ Ibid., h. 33. 
a) Guru menerangkan landasan kependidikan.

b) Guru memahami keberagaman siswa.

c) Guru mengembangkan silabus.

d) Guru menyusun rencana pembelajaran.

e) Guru menyusun strategi pembelajaran.

f) Guru melaksanakan pembelajaran yang mendidik.

g) Guru melaksanakan pembelajaran yang dialogis.

h) Guru melakukan evaluasi hasil belajar.

i) Guru mengembangkan bakat siswa dalam pembelajaran.

j) Guru mengembangkan minat siswa dalam pembelajaran.

k) Guru melakukan kegiatan intrakurikuler.

1) Guru melakukan kegiatan ekstrakurikuler.

3) Kompetensi Profesional

Kompetensi profesional merupakan penguasaan materi pembelajaran secara luas dan mendalam, yang mencakup penguasaan materi kurikulum mata pelajaran di sekolah dan substansi keilmuan yang menaungi materinya, serta penguasaan terhadap struktur dan metodologi keilmuan.

Menurut Slamet PH sebagaimana dikutip oleh Syaiful Sagala, kompetensi profesional berkaitan dengan bidang studi, yaitu:

a) memahami mata pelajaran yang telah dipersiapkan untuk mengajar. 
b) memahami standar kompetensi dan standar isi mata pelajaran yang tertera dalam Peraturan Menteri serta bahan ajar yang ada dalam kurikulum tingkat satuan pendidikan (KTSP).

c) memahami struktur, konsep, dan metode keilmuan yang menaungi materi ajar.

d) memahami hubungan konsep antar mata pelajaran terkait.

e) menerapkan konsep-konsep keilmuan dalam kehidupan sehari-hari. ${ }^{30}$

Dalam Undang-undang nomor 14 tahun 2005 Pasal 1 ayat (1) menyatakan guru adalah pendidik profesional dengan tugas utama mendidik, mengajar, membimbing, mengarahkan, melatih, menilai, dan mengevaluasi peserta didik pada pendidikan anak usia dini jalur pendidikan formal, pendidikan dasar, dan pendidikan menengah. ${ }^{31}$

Dengan demikian dapat disimpulkan bahwa kompetensi profesional mencakup kemampuan guru dalam menerapkan sejumlah konsep, asas kerja sebagai guru, mampu mendemonstrasikan sejumlah strategi maupun pendekatan pengajaran yang menarik dan interaktif, disiplin, jujur, dan konsisten.

Hal ini dapat dilihat dari aspek-aspek sebagai berikut:

${ }^{30}$ Ibid., h. 32.

${ }^{31}$ Undang-undang nomor 14 tahun 2005. 
Vol. V, No. 1, April 2017

a) Memahami mata pelajaran yang telah disiapkan.

b) Memahami standar kompetensi dan standar isi mata pelajaran.

c) Memahami hubungan konsep antar mata pelajaran terkait.

d) Menerapkan konsep keilmuan dalam kehidupan sehari-hari. $^{32}$

Peranan guru sangat menentukan keberhasilan proses pembelajaran, guru yang digugu dan ditiru adalah suatu profesi yang mengutamakan intelektualitas, kepandaian, kecerdasan, keahlian berkomunikasi, kebijaksanaan dan kesabaran tinggi. Tidak semua orang dapat menekuni profesi guru dengan baik. Karena jika seseorang tampak pandai dan cerdas bukan penentu keberhasilan orang tersebut menjadi guru.

4) Kompetensi Sosial

Kompetensi sosial terkait dengan kemampuan guru sebagai makhluk sosial dalam berinteraksi dengan orang lain. Sebagai makhluk sosial guru berperilaku santun, mampu berkomunikasi dan berinteraksi dengan lingkungan secara efektif dan menarik mempunyai rasa empati terhadap orang lain. Kemampuan guru berkomunikasi dan berinteraksi secara efektif dan menarik dengan peserta didik, sesama pendidik, dan

\section{h. 17 .}

${ }^{32}$ Syaiful Sagala, Kemampuan Profesional Guru dan Tenaga Kependidikan ... 
tenaga kependidikan, orang tua dan wali peserta didik, masyarakat sekitar sekolah dan sekitar dimana pendidik itu tinggal, dan dengan pihak-pihak berkepentingan dengan sekolah. Kondisi objektif ini menggambarkan bahwa kemampuan sosial guru tampak ketika bergaul dan melakukan interaksi sebagai profesi maupun sebagai masyarakat, dan kemampuan mengimplementasikan dalam kehidupan sehari-hari.

Secara ringkas kompetensi sosial guru dapat digambarkan sebagai berikut:

a) berkomunikasi lisan dan tulisan.

b) menggunakan teknologi komunikasi dan informasi secara fungsional.

c) bergaul secara efektif dengan peserta didik, sesama pendidik, tenaga kependidikan, orang tua/wali peserta didik, dan.

d) berbagi secara santun dengan masyarakat sekitar. $^{33}$

Sementara itu, Soetjipto dan Kosasi menjelaskan bahwa kompetensi sosial menunjukkan seorang profesional dalam melaksanakan harus dilandasi nilainilai kemanusiaan, dan kesadaran akan dampak lingkungan hidup dari efek pekerjaannya. ${ }^{34}$

${ }^{33}$ Ibid., h. 121.

${ }^{34}$ Soetjipto dan Kosasi, Profesi Keguruan, (Jakarta: Rajawali Press, 2004), h. 276. 
Vol. V, No. 1, April 2017

Dengan demikian dapat disimpulkan bahwa kompetensi sosial mencakup perangkat perilaku yang menyangkut kemampuan interaktif yaitu kemampuan yang menunjang efektivitas interaksi dengan orang lain terhadap diri sendiri, menafsirkan motif orang lain, mencapai rasa aman bersama orang lain. Keterampilan memecahkan masalah kehidupan seperti mengatur waktu, uang, kehidupan berkeluarga, memahami nilai kehidupan, dan sebagainya.

Hal tersebut dapat dilihat dari aspek-aspek sebagai berikut:

a) Berkomunikasi secara lisan dan tulisan.

b) Menggunakan teknologi komunikasi dan informasi secara fungsional.

c) Bergaul secara efektif dengan siswa, sesama guru, dan orang tua siswa.

d) Santun dengan masyarakat sekitar.

\section{Hipotesis}

Hipotesis merupakan jawaban sementara terhadap masalah penelitian yang secara teoritis diangggap paling mungkin dan paling tinggi tingkat kebenarannya. Sehubungan dengan permasalahan penelitian ini yaitu mengenai ada tidaknya pengaruh kepemimpinan kepala sekolah terhadap kompetensi gurudi SDN 035 Tembilahan, hipotesis yang diajukan dalam penelitian ini adalah: 
Ha : Terdapat pengaruh yang positif dan signifikan antara pengaruh kepemimpinan kepala sekolah terhadap kompetensi gurudi SDN 035 Tembilahan

Ho : Tidak terdapat pengaruh yang positif dan signifikan antara pengaruh kepemimpinan kepala sekolah terhadap kompetensi gurudi SDN 035 Tembilahan.

\section{Metodologi Penelitian}

Metode penelitian yang digunakan adalah dengan menggunakan pendekatan ekpos fakto yang dilaksanakan di SDN 035 Tembilahan. Populasi yang digunakan dalam penelitian ini adalah 1 orang kepala sekolah dan 34 orang guru di SDN 035 Tembilahan. Adapun sampel yang digunakan yaitu sampling jenuh. Sampling jenuh adalah teknik penentuan sampel bila semua anggota populasi digunakan sebagai sampel, karena jumlah populasi relatif kecil yaitu kurang dari 30 orang maka semua populasi dijadikan sampel. Jadi, jumlah sampel yang digunakan adalah 35 orang dengan teknik pengumpulan data melalui observasi, angket dan dokumentasi. Dan teknik analisis data yang digunakan dalam penelitian ini adalah deskriftif kualitatif dengan persentase dan analisis regresi sederhana.

\section{E. PembahasanHasil Penelitian}

Kepemimpinan kepala sekolah merupakan bentuk dari kinerja kepala sekolah sebagai pemimpin yang mengarahkan serta membimbing bawahan seperti guru dan staf kependidikan secara terpadu guna melaksanakan program pendidikan yang telah disusun dan 
Vol. V, No. 1, April 2017

direncanakan sebelumnya. Keberhasilan dan kesuksesan pelaksanaan kepemimpinan kepala sekolah dalam mengelola sekolah dipengaruhi oleh keterampilan yang dimilikinya.

Kepala sekolah memiliki tugas dan tangggungjawab dalam meningkatkan kompetensi guru. Kompetensi guru yang baik akan berdampak kepada kualitas proses belajar mengajar dikelas sehingga tujuan pendidikan dapt tercapai secara maksimal.

Kepala sekolah sebagai pemimpin lembaga pendidikan berimplikasi terhadap seluruh komponen yang ada disekolah terutama guru. Kepemimpinan kepala sekolah yang baik senantiasa akan membina dan mengembangkan kompetensi gurunya dalam berbagai kegiatan seperti KKG, seminar, loka karya dan sebagainya yang pelaksanaannya difasilitasi oleh kepala sekolah sebagai pemimpin.

Hasil penelitian ini menunjukkan bahwa ada pengaruh yang positif dan signifikan antara kepemimpinan kepala sekolah dengan kompetensi guru, hal ini ditunjukkan dengan tingginya pengaruh kepemimpinan kepala sekolah terhadap kompetensi guru yaitu sebesar $62,41 \%$.

Kepemimpinan kepala sekolah terlaksana dengan baik dalam mempengaruhi kompetensi guru. Hal ini dapat dilihat dari korelasi variabel $\mathrm{x}$ terhadap variabel y menunjukkan bahwa kepemimpinan kepala sekolah 62,41\% mempengaruhi kompetensi guru. dan 37,59\% kepemimpinan kepala sekolah dipengaruhi oleh faktor lain.

Oleh karena itu, dampak dari penelitian ini akan berpengaruh pada kualitas kepemimpinan kepala sekolah terhadap kompetensi guru 
disekolah sehingga terciptanya proses belajar mengajar yang efektif dan efesien.

\section{F. Kesimpulan}

Dari penjelasan yang penulis paparkan di atas dapat diambil kesimpulan sebagai berikut :

1. Kepemimpinan Kepala Sekolah di SDN 035 Tembilahan memperoleh hasil persentase akhir 64,15 dengan kategori baik, dimana terletak pada interval 61-80\%.

2. Kompetensi Guru di SDN 035 Tembilahan yang memperoleh hasil persentase akhir 77,13 dengan kategori baik, dimana terletak pada interval $61-80 \%$.

3. Untuk mengetahui apakah ada pengaruh atau tidaknya, penulis melakukan analisis data dengan menggunakan regresi sederhna disimpulkan bahwa terdapat pengaruh yang positif dan signifikan antara kepemimpinan kepala sekolah terhadap kompetensi guru, karena Karena $F_{\text {hitung }}=5,40>F_{\text {tabel }}=4,15$ maka $\mathrm{H}_{\mathrm{o}}$ ditolak. 
Vol. V, No. 1, April 2017

\section{DAFTAR PUSTAKA}

Daryanto, 2002, Kepala Sekolah Sebagai Pemimpin Pembelajaran, Yogykarta: Gava Media.

E. Mulyasa, 2006, Menjadi Kepala Sekolah Profesional, Bandung: PT. Remaja Rosdakarya

Herabudin, 2009, Administrasi dan Supervisi Pendidikan, Bandung: Pustaka Setia.

Ibrahim Bafadal, 2003, Peningkatan Profesionalisme Guru, Jakarta: Bumi Aksara.

Iskandar Agung dan Yufridawati, 2013, Pengembangan Pola Kerja Harmonis dan Sinergis Antara Guru, Kepala Sekolah, dan Pengawas, Jakarta: Bestari Buana Murni.

Kunandar, 2007, Guru Profesional Implementasi KTSP dan Sukses dalam Sertifikasi Guru, Jakarta: Rajawali Press

Maimunah, 2013, Manajemen Konflik dan Strategi Kepemimpinan Rasulullah SAW, Yogyakarta: Total Media.

Moh. Uzer Usman, 2003, Menjadi Guru Profesional, Bandung: Remaja Rosdakarya.

Sahertian, 2000, Konsep-Konsep dan Teknik Supervisi Pendidikan Dalam Rangka Pengembangan Sumber Daya Manusia, Jakarta: Rineka Cipta.

Soetjipto dan Kosasi, 200,Profesi Keguruan, Jakarta: Rajawali Press.

Sudarwan Danim, 2010, Kepemimpinan Pendidikan, Bandung: Alfabeta.

SutisnaOteng, 2008, Pemimpin Profesional, Bandung: Alfabeta.

Syaiful Sagala, 2009, Kemampuan Profesional Guru dan Tenaga Kependidikan, Bandung: Alfabeta. 
Tholib Kasan, 2006, Teori dan Aplikasi Administrasi Pendidikan, Jakarta: Studia Press

Tim Reality, 2008, Kamus Bahasa Indonesia, Surabaya: Reality Publisher.

Udin Syaefudin Saud, 2009, Profesi Guru, Bandung: Alfabeta.

Undang-undang Guru dan Dosen Nomor 14/2005 dan Peraturan Pemerintah Nomor 19/2005

Undang-Undang Republik Indonesia Nomor 20 Tahun 2003 tentang Standar Kompetensi Guru.

Yamin Martinis dan Maisah, 2010, Standarisasi Kinerja Guru, Jakarta: Gaung Persada Press. 
58 | Jurnal Al-Afkar

Vol. V, No. 1, April 2017 